\title{
The Role of Cooling Condition on the Superconducting Properties of $\mathrm{Tl}_{2-\mathrm{x}} \mathrm{Hg}_{\mathrm{x}} \mathrm{Sr}_{2} \mathrm{Ca}_{2} \mathrm{Cu}_{3} \mathrm{O}_{10+\delta}$ System
}

\author{
Amal K. Jassim, Maysoon F. A. Alias, Matti N. Makadsi \\ Physics Department, College of Science, University of Baghdad, Baghdad, Iraq \\ Email: amelalmalki1974@yahoo.com
}

How to cite this paper: Jassim, A.K., Alias, M.F.A. and Makadsi, M.N. (2019) The Role of Cooling Condition on the Superconducting Properties of $\mathrm{Tl}_{2-\mathrm{x}} \mathrm{Hg}_{\mathrm{x}} \mathrm{Sr}_{2} \mathrm{Ca}_{2} \mathrm{Cu}_{3} \mathrm{O}_{10+\delta}$ System. Advances in Materials Physics and Chemistry, 9, 133-140.

https://doi.org/10.4236/ampc.2019.98011

Received: July 29, 2019

Accepted: August 25, 2019

Published: August 28, 2019

Copyright $\odot 2019$ by author(s) and Scientific Research Publishing Inc. This work is licensed under the Creative Commons Attribution International License (CC BY 4.0).

http://creativecommons.org/licenses/by/4.0/

\begin{abstract}
Solid state reaction method was used to prepare high temperature superconductor with a nominal composition $\mathrm{Tl}_{2-\mathrm{x}} \mathrm{Hg}_{\mathrm{x}} \mathrm{Sr}_{2} \mathrm{Ca}_{2} \mathrm{Cu}_{3} \mathrm{O}_{10+\delta}(0 \leq \mathrm{x} \leq 1)$. The effect of quenching on the superconducting properties has been investigated by preparing two sets of samples at $1133 \mathrm{~K}$ for $3 \mathrm{hrs}$. The superconducting properties of the samples have been examined by electrical measurements. It is found that a partial substitution for $\mathrm{Tl}$ by $\mathrm{Hg}$ increases the formation of high- $\mathrm{T}_{\mathrm{c}}$ phase and increases its $\mathrm{T}_{\mathrm{c}}$. X-ray diffraction (XRD) pattern analyses have shown a tetragonal structure, and there are at least two superconducting phases.
\end{abstract}

\section{Keywords}

Superconductor, Microstructure Properties, TBCCO System

\section{Introduction}

The most interesting crystal chemical aspect of the high temperature superconductivity (HTSc) is that for those based on $\mathrm{Tl}$, there exists not only variable numbers of $\mathrm{Cu}-\mathrm{O}$ layers but also variable numbers of Tl-O layers, which provide the possibility of many compounds, in what is really an infinitely adoptive series through the process of substitution and the interrelated variation of its elements. The whole series can be written as: $\mathrm{TL}_{\mathrm{m}} \mathrm{Ba}_{2} \mathrm{Ca}_{\mathrm{n}-1} \mathrm{Cu}_{\mathrm{n}} \mathrm{O}_{\mathrm{m}+2 \mathrm{n}+2}$ and $\mathrm{TL}_{\mathrm{m}} \mathrm{Sr}_{2} \mathrm{Ca}_{\mathrm{n}-1} \mathrm{Cu}_{\mathrm{n}} \mathrm{O}_{\mathrm{m}+2 \mathrm{n}+2}$ [1]; the subscript $\mathrm{m}$ defines how many rock salt layers are present. The number of copper layers is remarkably variable, with $n=1,2,3$ and 4 presently claimed to be prepared as bulk material. Even more remarkably, all compounds, synthesized in this series, are claimed to be superconducting with $T_{c}$ 's greater than $80 \mathrm{~K}$. The desirable phase is the $m=2$ and $n=3$ phase, 
$\mathrm{Tl}_{2} \mathrm{Ba}_{2} \mathrm{Ca}_{2} \mathrm{Cu}_{3} \mathrm{O}_{10+\delta}$ (2223) because of its higher $\mathrm{T}_{c}$ [2]. Discoveries of Tl-based system have not only set new $\mathrm{T}_{\mathrm{c}}$ records with zero resistance up to $125 \mathrm{~K}$, but also have provided a new insight into the mechanism of high- $\mathrm{T}_{\mathrm{c}}$ oxide superconductivity [3].

Two superconducting phases, $\mathrm{Tl}_{2} \mathrm{Ca}_{2} \mathrm{Ba}_{2} \mathrm{Cu}_{3} \mathrm{O}_{10+\delta}$ and $\mathrm{Tl}_{2} \mathrm{Ca}_{1} \mathrm{Ba}_{2} \mathrm{Cu}_{2} \mathrm{O}_{8+\delta}$ were identified in their samples by Hazan et al. [4]. They found that these phases have a pseudo tetragonal until cell $(5.40 \times 5.40 \times 36.25) \AA$, corresponding to a, b and c lattice dimensions, respectively. In the same year, Parkin et al. [5] found that $\mathrm{T}_{\mathrm{c}}$ in $\mathrm{Tl}_{2} \mathrm{Ba}_{2} \mathrm{Ca}_{2} \mathrm{Cu}_{3} \mathrm{O}_{\mathrm{X}}$ system prepared by a solid state reaction method varies from $118 \mathrm{~K}$ to $125 \mathrm{~K}$ depending on preparation conditions. The transmission electron spectroscopy shows that the unit cell is a body-centered tetragonal and contains trilayer $\mathrm{Cu}$ perovskite units separated by bilayer Tl-O units with $\mathrm{a}=3.82$ and $\mathrm{c}=$ $12.00 \AA$ A. $\mathrm{T}_{\mathrm{c}}$ (zero) was found to be $78,96,106,98,45$ and $25 \mathrm{~K}$ for $\mathrm{Tl}_{0.5} \mathrm{Ca}_{1-\mathrm{x}} \mathrm{Pr}_{\mathrm{x}} \mathrm{Sr}_{2} \mathrm{Cu}_{2}$ oxide sample with $\mathrm{x}=0,0.1,0.2,0.5$ and 0.7 , respectively and for $\mathrm{x}=1$, the sample exhibited a semiconductor behavior.

Kaell et al. (1991) [6] studied the variation of $\mathrm{T}_{\mathrm{c}}$ due to partial Sr substitution, for $\mathrm{Ba}$ in $\mathrm{Tl}_{2} \mathrm{Ba}_{2-\mathrm{x}} \mathrm{Sr}_{\mathrm{x}} \mathrm{Ca}_{1} \mathrm{Cu}_{2} \mathrm{O}_{8}$ (Tl-2212), ( $\mathrm{x}=0$ - 0.6), and $\mathrm{Tl}_{2} \mathrm{Ba}_{2-\mathrm{x}} \mathrm{Sr}_{\mathrm{x}} \mathrm{Cu}_{1} \mathrm{O}_{6}$ $(\mathrm{Tl}-2201)(\mathrm{x}=0-0.6)$. They showed that, $\mathrm{T}_{\mathrm{c}}$ decreases rapidly with increasing $\mathrm{Sr}$ content for both Tl-2212 and Tl-2201 systems.

Bulk polycrystalline $\mathrm{Tl}_{2} \mathrm{Ba}_{2} \mathrm{CaCu}_{2} \mathrm{O}_{\mathrm{x}}$ system has been fabricated by Ossandon et al. (2001) [7]. Results showed that the crystalline unit cell is tetragonal with lattice constant $\mathrm{a}=3.8550 \AA$ and $\mathrm{c}=29.318 \AA$ (cell volume of $2.18 \times 10^{-23} \mathrm{~m}^{3}$ ) containing two sets of adjacent oxygen copper layers. The samples were irradiated at room temperature in air with $0.8 \mathrm{GeV}$ protons. The superconductive properties of the virgin and irradiated materials were investigated magnetically.

Eu-substituted $\left(\mathrm{Tl}_{0.6} \mathrm{~Pb}_{0.4}\right)\left(\mathrm{Sr}_{0.9} \mathrm{Ba}_{0.1}\right)_{2}\left(\mathrm{Ca}_{1-\mathrm{x}} \mathrm{Eu}_{\mathrm{x}}\right) \mathrm{Cu}_{2} \mathrm{O}_{4}$, for $\mathrm{x}=0.2,0.4$, and 0.6 compounds were prepared by Kuzman et al. (2004) [8]. They demonstrated that Eu can be substituted for $\mathrm{Ca}$ in separating the layer between $\mathrm{Cu}-\mathrm{O}$ conducting layers, $\mathrm{Cu}$ atoms are in the center of the basal plane of pyramids of the conducting layers, in the spacing layer $\mathrm{Ba}$ atoms are shown, and oxygen atoms are situated both in the corners of the pyramids and in the insulating layer, surrounded by $\mathrm{Tl}$ atoms.

Maysoon et al. [9] studied the effect of sintering time on superconducting properties of $\mathrm{Tl}_{1.6} \mathrm{Hg}_{0.4} \mathrm{Sr}_{2} \mathrm{Ca}_{2} \mathrm{Cu}_{3} \mathrm{O}_{10+\delta}$ and $\mathrm{Tl}_{1.8} \mathrm{Bi}_{0.2} \mathrm{Sr}_{2} \mathrm{Ca}_{2} \mathrm{Cu}_{3} \mathrm{O}_{10+\delta}$ compounds. They found that the optimum sintering time which was characteristic for the growth of high-Tc phase equal to $3 \mathrm{~h}$ and prolonging the sintering time to $6 \mathrm{~h}$ lead to decrease the transition temperature.

In this paper the impact of quenching in air was investigated on the structural and electrical properties of $\mathrm{Tl}_{2-\mathrm{x}} \mathrm{Hg}_{\mathrm{x}} \mathrm{Sr}_{2} \mathrm{Ca}_{2} \mathrm{Cu}_{3} \mathrm{O}_{10+\delta}$ system type 2223.

\section{Experimental}

The solid state reaction technique has been used to prepare homogeneous and well-defined single phase superconducting samples with uniform oxygen stoichiometry evolution of accurate physical parameters. Solid state reaction is the 
least expensive and largest batch size of any powder fabrication process, the procedure involves a simple blending of the required precursors, followed by one or more reactions at a high temperature [10].

So appropriate amounts of high purity $\mathrm{Tl}_{2} \mathrm{O}_{3}, \mathrm{Hg}_{2} \mathrm{O}, \mathrm{Sr}\left(\mathrm{NO}_{3}\right)_{2}, \mathrm{CaO}$ and $\mathrm{CuO}$ powders have been weighed stoichiometrically. Precursor $\mathrm{Sr}_{2} \mathrm{Ca}_{2} \mathrm{Cu}_{3} \mathrm{O}_{10+\delta}$ was first prepared using high purity powders of $\mathrm{Sr}\left(\mathrm{NO}_{3}\right)_{2}, \mathrm{CaO}$ and $\mathrm{CuO}$ as starting materials. Then, $\mathrm{Tl}_{2} \mathrm{O}_{3}$ and $\mathrm{Hg}_{2} \mathrm{O}$ were added to the mixture and grinding them in agate mortar to obtain a very fine powder. The mixtures were pressed into a pellet of $(0.2-0.3) \mathrm{cm}$ thickness and $1.3 \mathrm{~cm}$ diameter, under a pressure of about $3 \mathrm{ton} / \mathrm{cm}^{2}$. The samples were sintered in air atmosphere at temperture $1133 \mathrm{~K}$ for $3 \mathrm{hrs}$ in order to make the particles of the materials joined together and gradually reduce the volume of pore spaces between them. The most common method of determining $\mathrm{T}_{\mathrm{c}}$ of a superconductor is the resistivity measurement by using the four-point probe method in a cryostat with presence of liquid nitrogen. The cryostat system joined to a rotary pump to get a pressure of $\left(\sim 10^{-2}\right.$ mbar) inside the cryostat by using (Edward Prini 12) gage, and joined also to a sensor of a digital thermometer type (RTD), and thermocouple type (T) near the sample position. Four wires have been connected to the cryostat, the outer connection were used for supplying the sample with current from D.C power supply type (6236A triple output), while the inner connections were used to measure the voltage drop by a digital nanovoltmeter type (KETHLEY 180) with sensitivity of about ( \pm 0.1 nanovolt).

The structure of the prepared samples was obtained by using X-ray diffractometer (XRD) type Philips having the following features (source: $\mathrm{Cu}_{\mathrm{ka}}$, voltage: 40 $\mathrm{kV}$, current: $20 \mathrm{~mA}$, wavelength: $1.5405 \AA$ ). A computer program [11] was used to calculate the lattice parameters a, b and c. This program is based on Cohen's least square method [12]. Scanning electron microscope (SEM) type, Jeol model JSM-5600 has been used to study the nature of grains and to analyze the surface morphology of the samples. The oxygen content in the oxide ceramic samples was determined by the simple iodometric titration technique [13].

\section{Results and Discussion}

Two sets of samples were produced for each superconducting compound, the first set of samples was allowed to cool to room temperature in a tube furnace that has programmable controller with a cooling rate $275 \mathrm{~K} / \mathrm{min}$, while the second set of samples was removed from the furnace and quenched in air. Figure 1 and Figure 2) illustrate the variation of resistivity with temperature for $\mathrm{Tl}_{2-\mathrm{x}} \mathrm{Hg}_{\mathrm{x}} \mathrm{Sr}_{2} \mathrm{Ca}_{2} \mathrm{Cu}_{3} \mathrm{O}_{10+\delta}$ samples. It is found that the substitution of $0.1,0.2,0.3$ and $0.4 \mathrm{Hg}$ content to the composition raise the transition temperature $\mathrm{T}_{\mathrm{c}}$ and more addition $(\mathrm{x}=0.5)$ decrease the critical temperature, and when $\mathrm{x} \geq 0.6$ our apparatus could not help us to obtain the value of $\mathrm{T}_{\text {cofff }}$ because it is less than the liquid nitrogen temperature. This result indicates that the $\mathrm{Hg}$ has catalytic effect on the reaction to form the high- $\mathrm{T}_{\mathrm{c}}$ phase (HTP) within the range $\mathrm{x}=0.1-0.4$. 
However, certain amount of $\mathrm{Hg}$ is necessary for the occurrence of this reaction, while excessive $\mathrm{Hg}$ substitution promotes another reaction, which is likely to assist the formation of low- $\mathrm{T}_{\mathrm{c}}$ phase instead of the high- $\mathrm{T}_{\mathrm{c}}$ phase [14] [15] [16].

From these figures and Table 1 the role of quenching enhancement on the critical transition temperature has been seen.

The above results demonstrate that it is interesting to prepare variety of Tl-2223 samples in order to obtain the optimum high- $\mathrm{T}_{\mathrm{c}}$ phase. Similar explanation was reported by Hermiz et al. [17]. Thus, such comprehensive and complementary procedures should be used for investigating $\mathrm{TlSrCaCuO}$ system to explore if there will be a light at the end of the channel to arrive to or near room temperature; high temperature is required for the initiation of the formation reaction of superconducting compound; a short duration heating minimizes the decomposition and quenching stabilizes the superconducting phase.

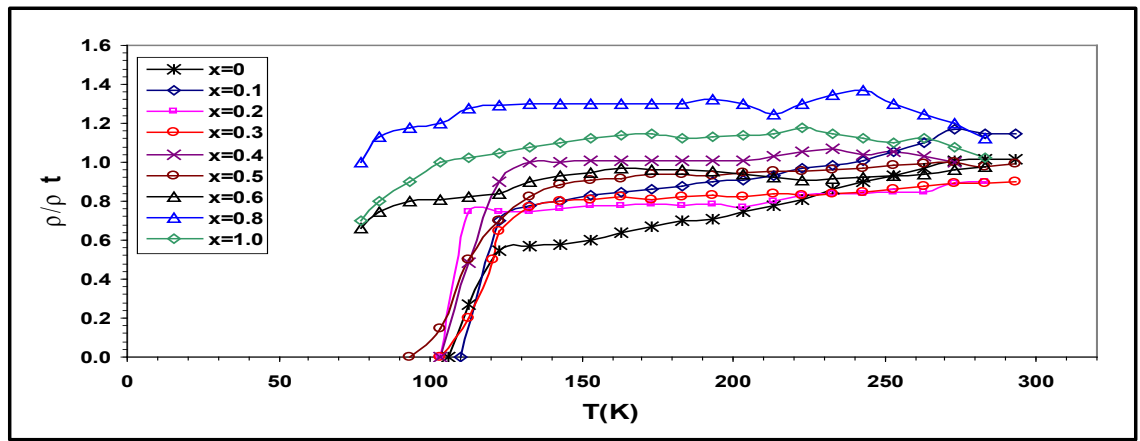

Figure 1. Temperature dependence of normalized resistivity for $\mathrm{Tl}_{2-\mathrm{x}} \mathrm{Hg}_{\mathrm{x}} \mathrm{Sr}_{2} \mathrm{Ca}_{2} \mathrm{Cu}_{3} \mathrm{O}_{10+\delta}$ samples for different $\mathrm{Hg}$ content (samples furnace cooled).

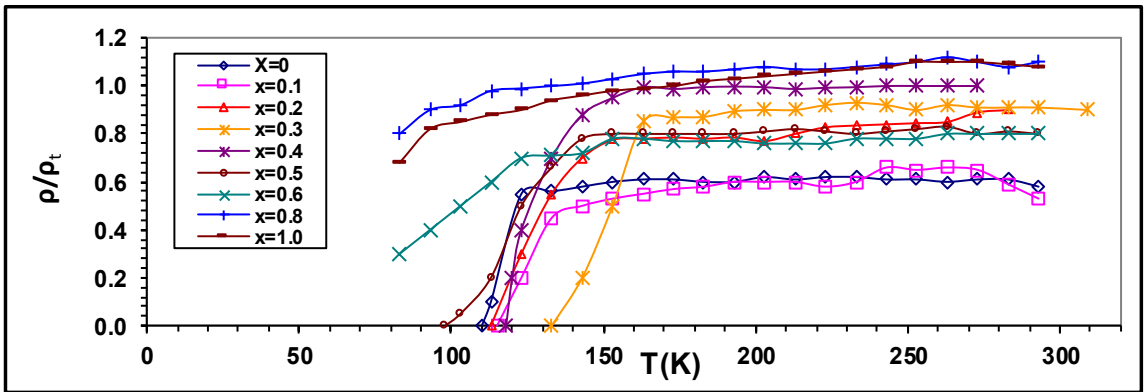

Figure 2. Temperature dependence of normalized resistivity for $\mathrm{Tl}_{2-\mathrm{x}} \mathrm{Hg}_{\mathrm{x}} \mathrm{Sr}_{2} \mathrm{Ca}_{2} \mathrm{Cu}_{3} \mathrm{O}_{10+\delta}$ system with different $\mathrm{Hg}$ content (samples quenched in air).

Table 1. Variation in $T_{c}$ values, lattice parameters and oxygen content with different cooling condition.

\begin{tabular}{cccccc}
\hline Sample & Cooling condition & $\mathrm{a}(\AA)$ & $\mathrm{c}(\AA)$ & $\mathrm{T}_{\mathrm{C}}(\mathrm{K})$ & $\delta$ \\
\hline \multirow{2}{*}{$\mathrm{Tl}_{2} \mathrm{Sr}_{2} \mathrm{Ca}_{2} \mathrm{Cu}_{3} \mathrm{O}_{10+\delta}$} & Furnace cooled & 4.350 & 33.78 & 110 & 0.189 \\
& Quenched in air & 4.150 & 34.37 & 118 & 0.250 \\
& Furnace cooled & 3.721 & 37.616 & 120 & 0.298 \\
$\mathrm{Tl}_{1.6} \mathrm{Hg}_{0.4} \mathrm{Sr}_{2} \mathrm{Ca}_{2} \mathrm{Cu}_{3} \mathrm{O}_{10+\delta}$ & Quenched in air & 4.056 & 37.889 & 130 & 0.301 \\
\hline
\end{tabular}


Some representative XRD patterns of the samples furnace cooled and quenched in air are shown in Figures 3-6. It is seen from these figures that the quenching enhances crystallinity and, the main peaks of these samples are attributed to the Tl-2223 phase with intensity higher than the furnace cooled samples peaks. The values of the lattice parameter a and $c$ for these samples are listed in Table 1. This table shows an increase of the c-axis lattice constant for Hg-doped samples as compared with the undoped samples, the reason is due to the substitution of $\mathrm{Hg}$ for $\mathrm{Tl}$ where the ionic radii of $\mathrm{Hg}^{2+}(1.11 \AA)$ is longer than that of $\mathrm{Tl}^{3+}(0.95 \AA)$ as mentioned previously which renders c-parameter to be longer or get deformed [18].

Most of the physical properties are very sensitive to the oxygen content in high- $\mathrm{T}_{\mathrm{c}}$ superconductors. Therefore, it is important to report the oxygen content of the sample on which the physical measurements are made.

The variation of cooling condition reflected on the $\mathrm{T}_{\mathrm{c}}$ and $\delta$ values, whereas higher $\mathrm{T}_{\mathrm{c}}$ and $\delta$ values are recorded in the quenched in air samples rather than the furnace cooled samples. This indicates that the increase in the $\mathrm{T}_{\mathrm{c}}$ and $\delta$ values are attributed to the increase of oxygen absorption during crystallization process of the superconductors [19].

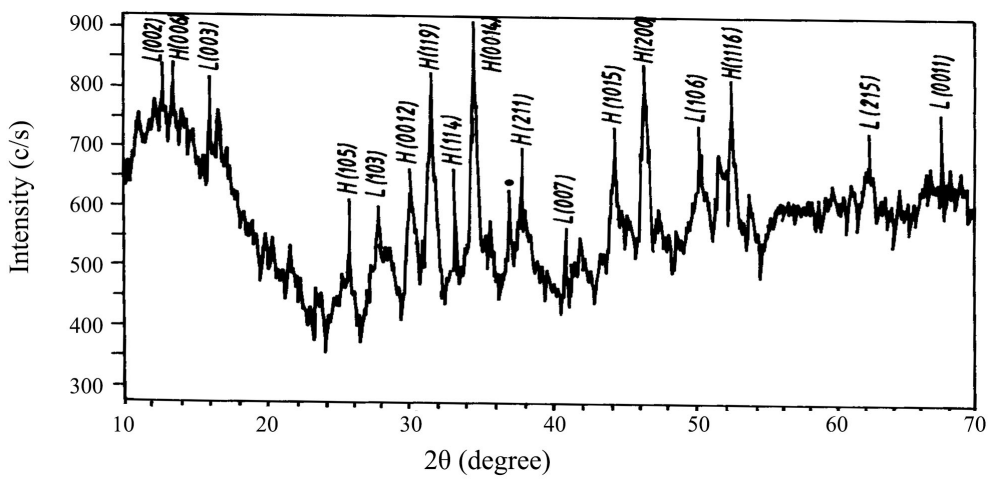

Figure 3. X-ray diffraction patterns of $\mathrm{Tl}_{2} \mathrm{Sr}_{2} \mathrm{Ca}_{2} \mathrm{Cu}_{3} \mathrm{O}_{10+\delta}$ samples sintered at $1133 \mathrm{~K}$ for $3 \mathrm{hrs}$ in air (samples furnace cooled). $\mathrm{H}-\mathrm{High} \mathrm{T}_{\mathrm{c}}$ phase, $\mathrm{L}-$ low $\mathrm{T}_{c}$ phase, -impurity phase $\left(\mathrm{Sr}_{2} \mathrm{Ca}_{2} \mathrm{Cu}_{7} \mathrm{O}\right)$.

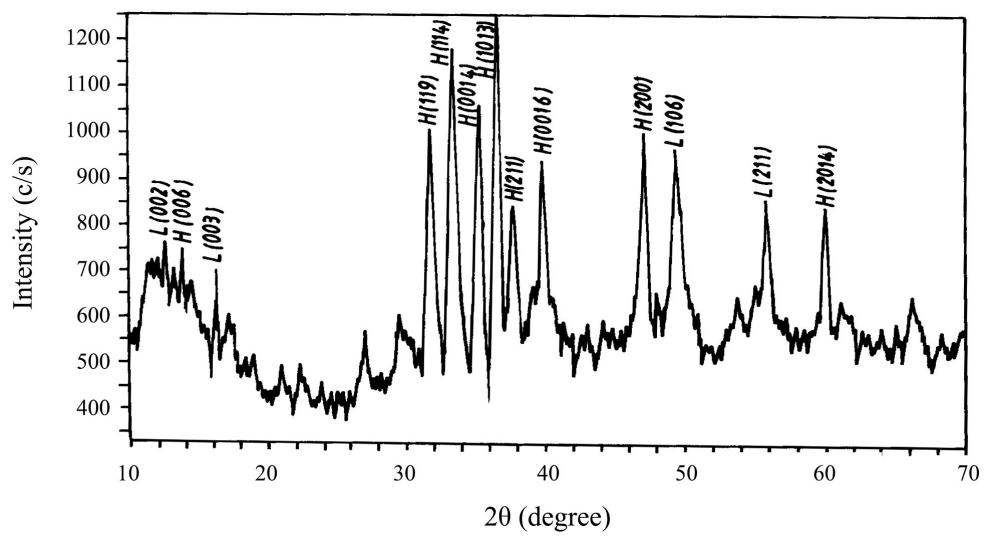

Figure 4. X-ray diffraction patterns of $\mathrm{Tl}_{2} \mathrm{Sr}_{2} \mathrm{Ca}_{2} \mathrm{Cu}_{3} \mathrm{O}_{10+\delta}$ samples sintered at $1133 \mathrm{~K}$ for $3 \mathrm{hrs}$ (samples quenched in air). $\mathrm{H}-$ High $\mathrm{T}_{\mathrm{c}}$ phase, $\mathrm{L}-$ Low $\mathrm{T}_{\mathrm{c}}$ phase. 
The important feature which can be inferred from the above result, the quenched in air samples improvement of links on intergranular inter faces of high- $\mathrm{T}_{c}$ phase (2223) and enhances the transition temperature.

It can clearly be seen from the micrographs which are shown in Figure 7 and Figure 8 that the quenched in air sample has less porous, high growth and bigger grain than that of the furnace cooled sample.

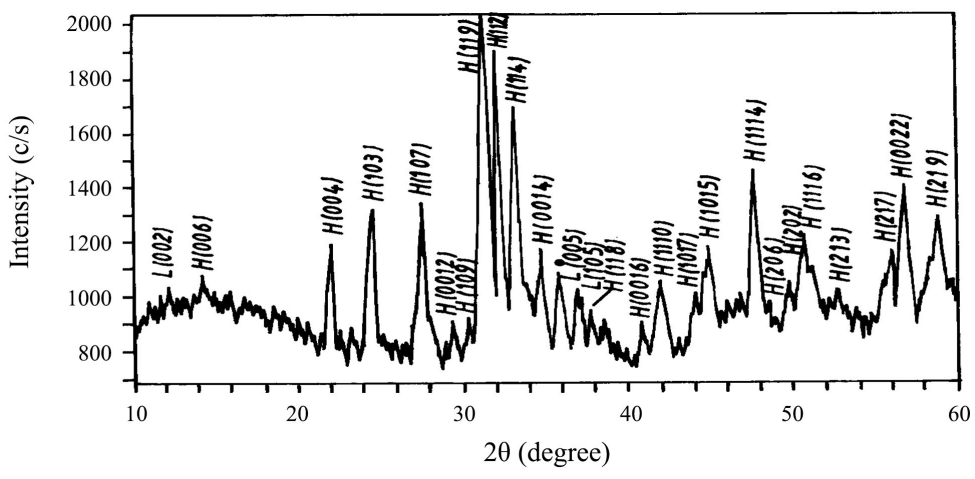

Figure 5. X-ray diffraction patterns of $\mathrm{Tl}_{1.6} \mathrm{Hg}_{0.4} \mathrm{Sr}_{2} \mathrm{Ca}_{2} \mathrm{Cu}_{3} \mathrm{O}_{10+\delta}$ samples sintered at $1133 \mathrm{~K}$ for $3 \mathrm{hrs}$ (samples furnace cooled). $\mathrm{H}-$ High $\mathrm{T}_{\mathrm{c}}$ phase, $\mathrm{L}-\mathrm{Low} \mathrm{T}_{\mathrm{c}}$ phase.

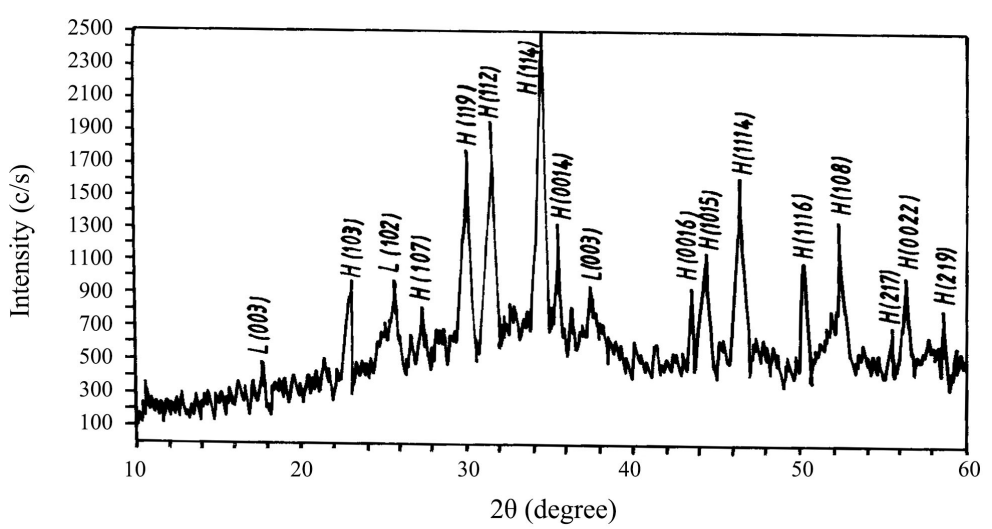

Figure 6. X-ray diffraction patterns of $\mathrm{Tl}_{1.6} \mathrm{Hg}_{0.4} \mathrm{Sr}_{2} \mathrm{Ca}_{2} \mathrm{Cu}_{3} \mathrm{O}_{10+\delta}$ samples sintered at $1133 \mathrm{~K}$ for 3 hrs (samples quenched in air). $\mathrm{H}-$ High $\mathrm{T}_{\mathrm{c}}$ phase, $\mathrm{L}-$ Low $\mathrm{T}_{\mathrm{c}}$ phase.

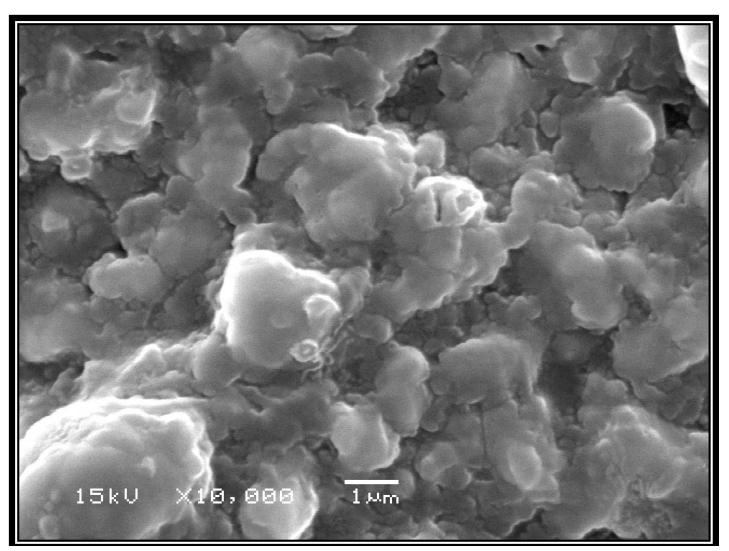

Figure 7. SEM micrographs of the fracture surfaces of $\mathrm{Tl}_{1.6} \mathrm{Hg}_{0.4} \mathrm{Sr}_{2} \mathrm{Ca}_{2} \mathrm{Cu}_{3} \mathrm{O}_{10+\delta}$ sample. 


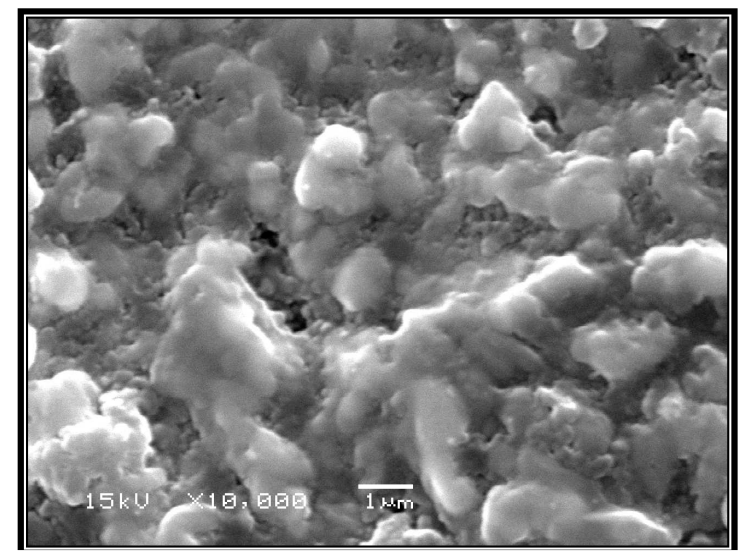

Figure 8. SEM micrographs of the fracture surfaces of $\mathrm{Tl}_{1.6} \mathrm{Hg}_{0.4} \mathrm{Sr}_{2} \mathrm{Ca}_{2} \mathrm{Cu}_{3} \mathrm{O}_{10+\delta}$ quenched sample.

\section{Conclusion}

A partial substitution of $\mathrm{Tl}$ by $\mathrm{Hg}$ was found to promote the formation and grain growth of Tl-2223 phase and then enhance the $T_{c}$ value. XRD pattern analyses have shown a tetragonal structure, and there were at least two superconducting phases. The dominant phase showed the mean composition corresponding to Tl-2223. Samples quenched in air showed a higher $T_{c}$ value, less porous, higher growth and bigger grains than the furnace cooled sample.

\section{Conflicts of Interest}

The authors declare no conflicts of interest regarding the publication of this paper.

\section{References}

[1] Cava, R.J. (1988) AT and T. Bell Laboratories, USA.

[2] Lynn, J.W. (1990) High Temperature Superconductivity. Springer-Verlag, Berlin. https://doi.org/10.1007/978-1-4612-3222-3

[3] Galasiewiez, Z.M. (1970) Superconductivity and Quantum Fluid. Pergamon Press, Warszawa.

[4] Hazen, R.M., Finger, L.W., Angel, R.J., Prewitt, C.T., Ross, N.L., Sheng, Z.Z. and Herman, A.M. (1988) 100-K Superconducting Phases in the Tl-Ca-Ba-Cu-O System. Physical Review Letters, 60, 1657. https://doi.org/10.1103/PhysRevLett.60.1657

[5] Parkin, S.S.P., Lee, V.Y., Engler, E.M., Nazzel, A.I., Huang, T.C., Gorman, G., Savoy, R. and Beyers, R. (1988) Bulk Superconductivity at $125 \mathrm{~K}$ in $\mathrm{Tl}_{2} \mathrm{Ca}_{2} \mathrm{Ba}_{2} \mathrm{Cu}_{3} \mathrm{O}_{\mathrm{x}}$. Physical Review Letters, 60, 2539. https://doi.org/10.1103/PhysRevLett.60.2539

[6] Käll, M., Börjensson, L., Kakihana, M., Stöm, C., G.Johansson, G., Ericksson, G. and Lasson, T. (1991) Changes in the Apical Oxygen Vibrational Frequency and $\mathrm{T}_{c}$ Due to Sr Substitution for $\mathrm{Ba}$ in $\mathrm{YB}_{2} \mathrm{Cu}_{3} \mathrm{O}_{7-\mathrm{y}}, \mathrm{TI}_{2} \mathrm{Ba}_{2} \mathrm{CaCu}_{2} \mathrm{O}_{8-\mathrm{y}}$ and $\mathrm{TI}_{2} \mathrm{Ba}_{2} \mathrm{CuO}_{6-\mathrm{y}}$ superconductors. Physica $C, \mathbf{1 8 5}, 821$.

[7] Osssandon, J.G., Thompson, J.R., Krusin-Elbaum, L., Km, H.J., Christen, D.K., Song, K.J. and Uiimann, J.L. (2001) Influence of Randomly Oriented Columnar De- 
fects on the Irreversible and Reversible Magnetization of $\mathrm{Tl}_{2} \mathrm{Ba}_{2} \mathrm{CaCu}_{2} \mathrm{O}_{\mathrm{x}}$ Superconductor. Superconductor Science and Technology, 14, 666. https://doi.org/10.1088/0953-2048/14/9/306

[8] Kuzman, K., Klencsar, Z., Sasvari, A., Homonnay, Z., Mair, M. and Vertes, A. (2004) Mössbauer Study of the Eu Substitution in (Tl,Pb)-1212 Superconductors. Physica C, 420, 17-22. https://doi.org/10.1016/j.physc.2004.12.011

[9] Alias, M.F., Jassim, A.K. and Hermiz, G.Y. (2017) Effect of sintering Time on the Superconducting Properties of $\mathrm{Tl}_{1.6} \mathrm{Hg}_{0.4} \mathrm{Sr}_{2} \mathrm{Ca}_{2} \mathrm{Cu}_{3} \mathrm{O}_{10+\delta}$ and Tl1.8Bi0.2Sr2Ca2Cu3O10+ $\delta$ Compound. International Journal of Science and Nature, 8.

[10] Verma, K.K., Tiwari, R.S. and Srivastava, O.N. (2005) Effect of Annealing Temperature on the Structural-Microstructural and Electrical Characteristics of Thallium Bearing HTSC Films Prepared by Chemical Spray Pyrolysis Technique. Bulletin of Materials Science, 28, 151-154. https://doi.org/10.1007/BF02704235

[11] Al-Shakarchi, E.Kh. (1997) The Variation of the Structure and Phase Transformation in $\mathrm{Y}-\mathrm{Ba}-\mathrm{Cu}-\mathrm{O}$ High Temperature Superconductor Compound with Isovalent Substitution. PhD Thesis, University of Baghdad, College of Science, Baghdad.

[12] Ferguson, I.F. and Rogerson, A.H. (1984) A Program for the Derivation of Crystal Unit Cell Parameters from X-Ray Powder Diffraction Measurements. Computer Physics Communications, 32, 95-107. https://doi.org/10.1016/0010-4655(84)90011-0

[13] Manthiram, A., Swinnea, J.S., Sui, Z.T., Steinfink, H. and Goodenough, J.B. (1987) The Influence of Oxygen Variation on the Crystal Structure and Phase Composition of the Superconductor Yttrium Barium Copper Oxide $\left(\mathrm{YBa}_{2} \mathrm{Cu}_{3} \mathrm{O}_{7-\mathrm{x}}\right)$. Journal of the American Chemical Society, 109, 6667-6669. https://doi.org/10.1021/ja00256a019

[14] Murayama, N., Awano, M., Sudo, E. and Torii, Y. (1988) Cation Contents and Superconducting Properties of the High-Tc Phase of Bi-Pb-Sr-Ca-Cu-O Ceramics. Journal of Applied Physics, 27, L2280. https://doi.org/10.1143/JJAP.27.L2280

[15] Jassim, A.K., Alias, M.F.A. and Abbas, M.M. (2017) Effect of Bi Substitution on the Superconducting Properties of $\mathrm{Tl}_{2-\mathrm{x}} \mathrm{Bi}_{\mathrm{x}} \mathrm{Ba}_{2} \mathrm{Ca}_{2} \mathrm{Cu}_{3} \mathrm{O}_{10+\delta}$ System. International Journal of Science and Nature, 8.

[16] Oota, A., Kirihigashi, A., Sasaki, Y. and Ohba, K. (1988) The Effect of Pb Addition on Superconductivity in Bi-Sr-Ca-Cu-O. Journal of Applied Physics, 27, L2289. https://doi.org/10.1143/JJAP.27.L2289

[17] Hermiz, G.Y., Jassim, A.K. and Oboudi, S.F. (2015) Electrical, Structural and Morphological Properties of Sb-Doped Bi-Based Superconductors. Advances in Materials Physics and Chemistry, 5, 214-220. https://doi.org/10.4236/ampc.2015.56022

[18] Alias, M.F., Maqadsi, M.N. and Jassim, A.K. (2010) Effect of Hg on Superconducting and Microstructure Properties of $\mathrm{Tl}_{2-\mathrm{x}} \mathrm{Hg}_{\mathrm{x}} \mathrm{Sr}_{2} \mathrm{Ca}_{2} \mathrm{Cu}_{3} \mathrm{O}_{10+\delta}$ Systems. Iraqi Journal of Physics, 8, L53.

[19] Giri, R., Singh, H.K., Tiwari, R.S. and Srivastava, O.N. (2001) Effect of Cationic Size in $\mathrm{Hg}(\mathrm{Tl} / \mathrm{Bi}) \mathrm{Ba}_{2} \mathrm{Ca}_{2} \mathrm{Cu}_{3} \mathrm{O}_{8+\delta}$ on Superconducting and Microstructural Characteristics. Bulletin of Materials Science, 24, 523-528. https://doi.org/10.1007/BF02706725 